\title{
Klasifikasi American Sign Language Menggunakan Ekstraksi Fitur Histogram of Oriented Gradients dan Jaringan Syaraf Tiruan
}

\author{
http://dx.doi.org/10.28932/jutisi.v6i3.2844
}

\author{
Muhammad Ezar Al Rivan ${ }^{\bowtie}$, Mochammad Trinanda Noviardy *2 \\ ${ }^{*}$ Teknik Informatika, STMIK Global Informatika MDP \\ Jalan Rajawali No.14 Palembang \\ ${ }^{1}$ meedzharemdp.ac.id \\ ${ }^{2} \mathrm{~m}$. trinandanoviardy@gmail.com
}

\begin{abstract}
Sign languages have various types, one of which is American Sign Language (ASL). In this study, ASL images from the handshape alphabet were extracted using Histogram of Oriented Gradient (HOG) then these features were used for the classification of Artificial Neural Networks (ANN) with various training functions using 3 variations of multi-layer network architecture where ANN architecture consists of one hidden layer. Based on ANN training, trainbr test results have a higher success rate than other training functions. In architecture with 15 neurons in the hidden layer get an accuracy value of $99.29 \%$, a precision of $91.84 \%$, and a recall of $91.47 \%$. The test results show that using the HOG feature and ANN classification method for ASL recognition gives a good level of accuracy, with an overall accuracy of 5 neurons 95.38\%, 10 neurons $96.64 \%$, and 15 neurons with $97.32 \%$.
\end{abstract}

Keywords- Artificial Neural Network; American Sign Language; Histogram of Oriented Gradient; Training Function

\section{Pendahuluan}

Komunikasi merupakan kunci penting dalam kehidupan manusia. Manusia harus mampu berkomunikasi dengan lingkungannya. Cara berkomunikasi mengalami perkembangan mengikuti kebutuhan seperti untuk memudahkan penderita tuna rungu berkomunikasi. Penderita tuna rungu memiliki cara berkomunikasi menggunakan anggota tubuh yang merepresentasikan bentuk huruf sehingga dibutuhkan bahasa untuk berkomunikasi dalam kegiatan sehari harinya berupa bahasa isyarat [1]. American Sign Language (ASL) merupakan salah satu dari bahasa isyarat yang umum digunakan. ASL adalah bahasa yang memiliki sifat linguistik yang sama dengan bahasa lisan yang diekspresikan dengan gerakan tangan. Gerakan-gerakan tangan ini dapat dikenali dengan memanfaatkan teknologi komputer.
Penelitian terkait dengan ASL sudah dilakukan oleh [2] dengan menggunakan fitur Histogram of Oriented Gradient dengan classifier yaitu $k$-Nearest Neighbor (k-NN). Selain itu, pada penelitian [3] pengenalan ASL menggunakan fitur Edge Oriented Histogram (EOH) dengan Image Matching. Penelitian ASL lain yang dilakukan [4] menggunakan fitur Scale Invariant Feature Transform (SIFT).

Fitur HOG digunakan untuk mengambil ciri bentuk pada citra. Pada penelitian [2] HOG digunakan pada pengenalan ASL. Pada penelitian lain juga HOG digunakan sebagai fitur bentuk untuk mengenali penyakit kulit [5]. Pada penelitian tersebut HOG dikombinasikan dengan Jaringan Syaraf Tiruan (JST). Pada penelitian [6] HOG digunakan untuk mengambil ciri bentuk tanaman kemudian dilakukan pengenalan menggunakan JST. HOG digunakan juga pada penelitian [7] sebagai fitur bentuk untuk iris.

JST salah satu metode yang digunakan untuk pengenalan objek. Metode JST telah digunakan pada penelitian [5] dan [6]. Selain itu JST juga digunakan untuk melakukan identifikasi glaukoma dan diabetes retinopati pada citra fundus [8]. Pada penelitian [9] JST digunakan untuk klasifikasi jenis kacang-kacangan menggunakan fitur Gray Level Co-occurence Matrix (GLCM). JST juga digunakan untuk menentukan kualitas biji kopi pada penelitian [10]. Pada penelitian [11] JST digunakan untuk identifikasi jenis tumbuhan dengan menggunakan citra daun. JST digunakan juga untuk pengenalan sign language seperti pada penelitian [12] dan [13] untuk pengenalan Japan Sign Language (JSL).

Berdasarkan penelitian sebelumnya fitur HOG dan JST untuk pengenalan citra memiliki tingkat akurasi yang baik untuk mengenali objek berdasarkan bentuk objek. Pada penelitian ini menggunakan ekstraksi fitur HOG dan menggunakan JST sebagai klasifikasi untuk pengenalan citra ASL. 


\section{STUdi LiTERATUR}

Penelitian terkait dengan ASL telah dilakukan oleh banyak peneliti. Pada penelitian [2] didapatkan hasil mencaai 99\% Metode yang digunakan yaitu HOG untuk ekstraksi fitur dan k-NN sebagai klasifikasi. Distance yang digunakan yaitu Euclidean Distance, Manhattan Distance dan Chebychev Distance. Pada penelitian [3] pengenalan ASL dilakukan dengan menggunakan EOH dan Image Matching memberikan hasil yang baik menggunakan Sum of Absolute Different dengan bentuk fitur 9 bin. Selain menggunakan HOG terdapat fitur lain seperti SIFT yang digunakan pada penelitian [4] yang memberikan hasil pengenalan yang baik.

Fitur HOG digunakan untuk mengambil fitur bentuk dari citra. Pada penelitian [14] HOG digunakan untuk mengambil fitur bentuk angka. Pada penelitian [5] fitur HOG dikombinasikan dengan JST untuk melakukan pengenalan penyakit kulit. Kombinasi HOG dan JST memberikan hasil akurasi 83,3\%. Kombinasi lain dari HOG dan JST digunakan untuk mengenali jenis tanaman yang dilakukan pada [6]. Hasil yang didapat mencapai 98,5\%. Pada penelitian [7] HOG dikombinasikan dengan k-NN digunakan untuk pengenalan iris memberikan hasil $96 \%$.

JST memberikan hasil pengenalan yang baik. JST yang digunakan pada penelitian [8] memberikan hasil sebesar $91 \%$ untuk pengenalan penyakit pada mata. Pada penelitian [9] menggunakan JST untuk pengenalan jenis kacangkacangan mendapat hasil $99,84 \%$. Selain itu JST juga digunakan untuk penentuan kualitas biji kopi yang dilakukan pada penelitian [10] memberikan hasil 80\%. Pada penelitian [11] JST digunakan untuk mengenali jenis-jenis daun memberikan hasil 93,6\%. JST juga digunakan untuk pengenalan Sign Language pada penelitian [12] yang mendapat hasil $81,11 \%$ dan penelitian [13] memberikan hasil $93 \%$.

\section{Metode Penelitian}

Tahapan yang dilakukan dalam penelitian ini yaitu menyiapkan dataset, kemudian melakukan pre-processing, ekstraksi fitur, dan melakukan klasifikasi. Alur kerja yang diajukan dapat dilihat pada Gambar 1.

\section{A. Dataset}

Dataset ini merupakan dataset publik yang dapat diakses secara bebas [15]. Dataset ini digunakan juga pada penelitian yang dilakukan oleh [2]. Dataset ini terdiri dari 24 huruf A sampai $\mathrm{Z}$ kecuali $\mathrm{J}$ dan $\mathrm{Z}$. Huruf $\mathrm{J}$ dan $\mathrm{Z}$ tidak digunakan karena huruf-huruf ini memerlukan pergerakan sehingga pengenalan tidak dapat dilakukan terhadap citra bergerak.

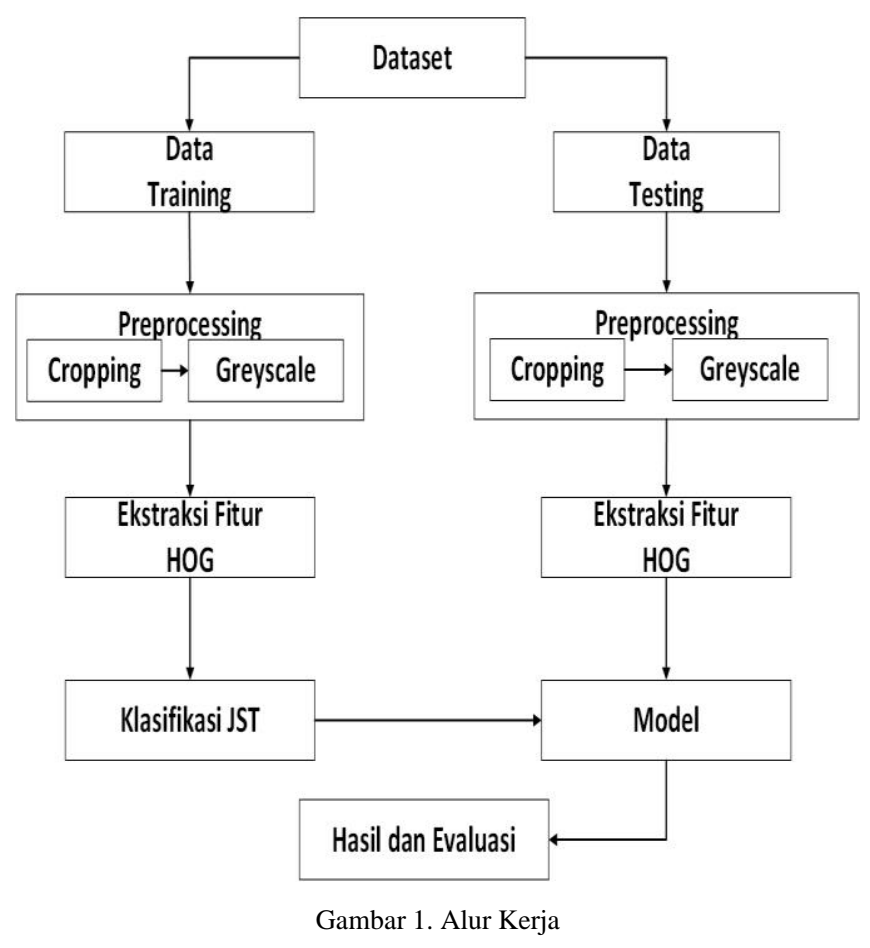

\section{B. Preprocessing}

Pada tahapan ini, dataset akan dilakukan proses cropping. Citra data yang dilatih dan diuji awalnya berukuran $320 \mathrm{x}$ 240 piksel. Selanjutnya akan melewati proses resize disimpan dengan ukuran $91 \times 91$ piksel. Ukuran tersebut dipilih agar citra yang dipakai lebih fokus pada jari dan telapak tangan user. Pada Gambar 2, Gambar 3, Gambar 4, Gambar 5 dan Gambar 6 merupakan contoh beberapa proses cropping yang dilakukan untuk huruf A sampai E.
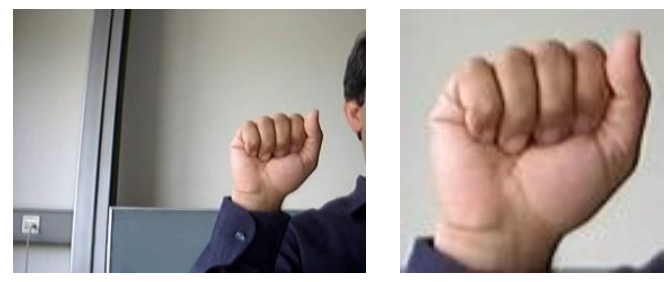

Gambar 2. Proses cropping citra asli huruf A (kiri) menjadi 91 x 91 (kanan)
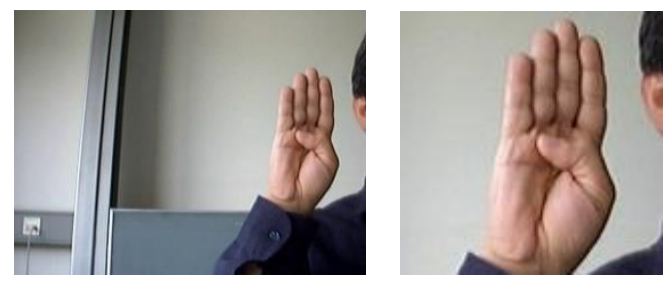

Gambar 3. Proses cropping citra asli huruf B (kiri) menjadi 91 x 91 (kanan) 

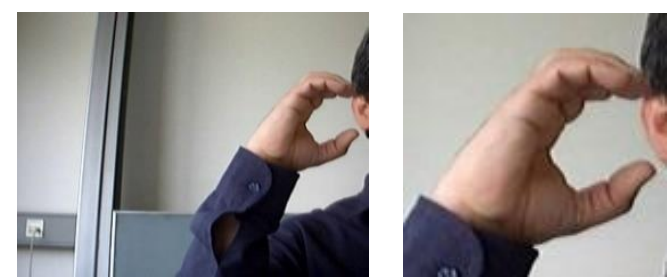

Gambar 4. Proses cropping citra asli huruf C (kiri) menjadi 91 x 91 (kanan)
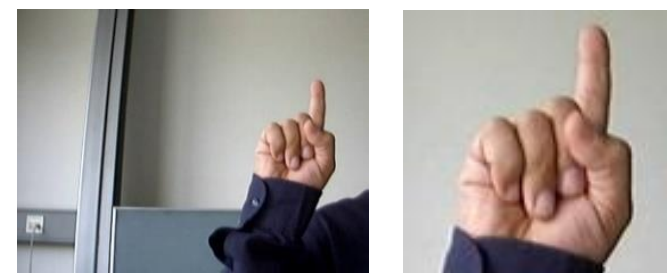

Gambar 5. Proses cropping citra asli huruf D (kiri) menjadi 91 x 91 (kanan)
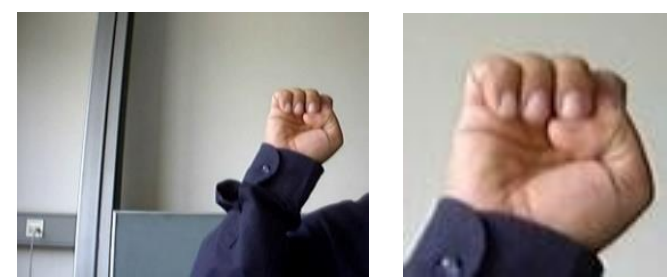

Gambar 6. Proses cropping citra asli huruf E (kiri) menjadi 91 x 91 (kanan)

\section{Ekstraksi Fitur}

Citra yang sudah melalui proses pre-processing selanjutnya dilakukan perubahan citra RGB menjadi greyscale pada setiap citra data training dan data testing. Pada setiap citra data training dan data testing yang melalui proses ekstraksi dan memperoleh fitur vector yang diperoleh panjangnya sebanyak 576. Hasil training menggunakan ekstraksi HOG didapat nilai vector berukuran 1176 x 576, sedangkan hasil testing didapat nilai vector berukuran $504 \mathrm{x}$ 576. Dari nilai tersebut maka proses selanjutnya melakukan klasifikasi menggunakan metode JST.

\section{PERANCANGAN JST UNTUK KLASIFIKASI ASL}

JST yang digunakan dalam penelitian ini memiliki 3 layer yaitu input layer, hidden layer dan output layer. Masing-masing layer memiliki neuron masing-masing yang dapat disesuaikan dengan kebutuhan.

\section{A. Rancangan JST untuk Klasifikasi ASL}

JST yang digunakan untuk klasifikasi ASL dapat dilihat pada Gambar 7. JST memiliki input layer terdiri dari 576 input yang merepresentasikan vektor fitur hasil ekstraksi HOG. Pada layer berikutnya yaitu hidden layer terdiri dari $n$ neuron yang disesuaikan dengan kebutuhan. Dalam penelitian ini digunakan $\mathrm{n}=\{5,10,15\}$. Pada layer terakhir output layer memiliki 24 neuron yang menyesuaikan dengan banyak huruf yang akan dikenali. Nilai pada output layer nantinya menunjukkan label dari huruf. Untuk huruf A maka pada neuron pertama bernilai 1 dan neuron yang lain bernilai 0. Sama halnya dengan huruf-huruf yang lain. Namun pengecualian pada huruf $\mathrm{J}$ dan Z. Oleh karena itu pada neuron kesepuluh digunakan untuk huruf $\mathrm{K}$, neuron kesebelas untuk huruf L dan seterusnya hingga neuron keduapuluhempat untuk huruf Y.

Hasil dari ekstraksi HOG disimpan dengan nama "data_hog_train" yang kemudian digunakan oleh JST untuk dilatih agar dapat mengenali huruf yang diberikan. Untuk target mengikuti label dari huruf yang disimpan dengan nama "targets_train".

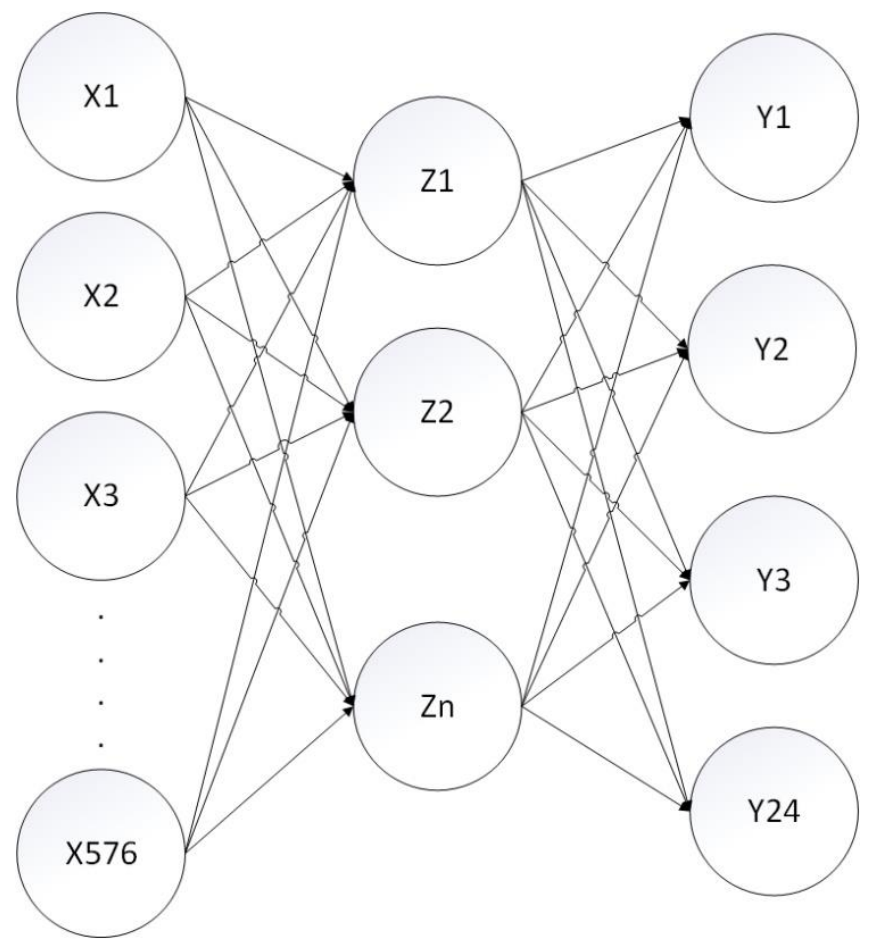

Gambar 7. Arsitektur Jaringan Saraf Tiruan

Setiap perpindahan layer setiap nilai akan dimasukkan ke dalam fungsi aktivasi. Fungsi aktivasi pertama terjadi ketika nilai berpindah dari input layer ke hidden layer. Kemudian fungsi aktivasi kedua terjadi pada saat perpindahan dari hidden layer ke output layer. Fungsi aktivasi yang digunakan yaitu fungsi aktivasi sigmoid. Fungsi sigmoid digunakan dikarenakan fungsi ini cocok untuk permasalahan non-linear.

\section{B. Training Function JST}

JST memiliki berbagai jenis training function. Training function digunakan sebagai subrutin untuk melatih JST. Pada tahap ini dilakukan skenario menggunakan berbagai jenis training function yang ada. Skenario lain juga dilakukan terhadap jumlah neuron pada hidden layer. Skenario yang dilakukan dapat dilihat pada Tabel I. 
TABEL I

SKENARIO TRAINING FUNCTION DAN JUMLAH NEURON

\begin{tabular}{|c|l|c|}
\hline No & \multicolumn{1}{|c|}{$\begin{array}{c}\text { Training } \\
\text { Function }\end{array}$} & $\begin{array}{c}\text { Jumlah Neuron yang } \\
\text { digunakan }\end{array}$ \\
\hline 1 & Trainbr & 5,10 dan 15 \\
\hline 2 & Trainlm & 5,10 dan 15 \\
\hline 3 & Trainbfg & 5,10 dan 15 \\
\hline 4 & Traincgb & 5,10 dan 15 \\
\hline 5 & Traincgf & 5,10 dan 15 \\
\hline 6 & Traincgp & 5,10 dan 15 \\
\hline 7 & Traingd & 5,10 dan 15 \\
\hline 8 & Traingda & 5,10 dan 15 \\
\hline 9 & Traingdm & 5,10 dan 15 \\
\hline 10 & Traingdx & 5,10 dan 15 \\
\hline 11 & Trainoss & 5,10 dan 15 \\
\hline 12 & Trainrp & 5,10 dan 15 \\
\hline 13 & Trainscg & 5,10 dan 15 \\
\hline 14 & Trainb & 5,10 dan 15 \\
\hline 15 & Trainc & 5,10 dan 15 \\
\hline 16 & Trainr & 5,10 dan 15 \\
\hline 17 & Trains & 5,10 dan 15 \\
\hline \multicolumn{2}{|c|}{} \\
\hline
\end{tabular}

\section{Confusion Matrix}

Hasil klasifikasi dihitung untuk mendapatkan tingkat keberhasilan dari metode yang digunakan, dengan menggunakan metode Confusion Matrix yang dimana akan menghitung nilai Precision, Recall, dan Accuracy [9]. Tabel Confusion Matrix dapat dilihat pada Tabel II.

TABEL II

CONFUSION MATRIX

\begin{tabular}{|c|c|c|c|}
\hline & & \multicolumn{2}{|c|}{ True Values } \\
\hline & & True & False \\
\hline \multirow{2}{*}{ 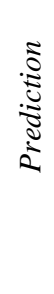 } & $\stackrel{5}{5}$ & $\begin{array}{c}\text { TP } \\
\text { Correct Result }\end{array}$ & $\begin{array}{c}F P \\
\text { Unexpected Result }\end{array}$ \\
\hline & 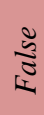 & FN Missing Result & $\begin{array}{c}\text { TN } \\
\text { Correct absence of } \\
\text { Result }\end{array}$ \\
\hline
\end{tabular}

Presision $=\frac{T P}{T P+F P}$

Recall $=\frac{T P}{T P+F N}$

Accuracy $=\frac{T P+T N}{T P+T N+F P+F N}$

Overall Accuracy = Total $(T P)+$ Total $(T N)$

$\overline{\text { Total }(T P)+\text { Total }(T N)+\text { Total }(F P)+\text { Total }(F N)}$

Dengan True Positive (TP) adalah jumlah data positif citra ASL yang terklasifikasi dengan benar oleh sistem. True Negative (TN) adalah jumlah data negatif citra ASL yang terklasifikasi dengan benar oleh sistem. False Negative (FN) adalah jumlah data negatif citra ASL namun terklasifikasi salah oleh sistem dan False Positive (FP) adalah jumlah data positif citra ASL namun terklasifikasi salah oleh sistem.

\section{IMPLEMENTASI JST, HASIL EKSPERIMEN DAN ANALISIS}

Pada Gambar 8 merupakan tampilan hasil dari proses training tool. Proses pelatihan jaringan syaraf tiruan dimulai dengan melakukan pembentukan jaringan syaraf tiruan itu sendiri menggunakan perintah net $=$ patternet $(10)$ dan net.trainFcn = 'trainbr' sebagai jaringan backpropagation yang terdiri dari $\mathrm{n}$ layer. Kemudian di-train menggunakan perintah $[n e t, t r]=$ train $\left(n e t, d a t a \_h o g \_t r a i n\right.$, targets_train $)$ dimana net merupakan jaringan backpropagation, data_hog_train merupakan hasil ekstraksi HOG serta target merupakan nilai target pada objek data latih. Selanjutnya diuji pelatihan jaringan syaraf tiruan dengan menggunakan perintah hasil_train $=$ net(data_hog_train) dimana akan menghasilkan inputan sebanyak 576, satu hidden layer dengan neuron berjumlah 10 dan 24 output dari 24 citra ASL. Arsitektur model JST ini menggunakan single hidden layer, nilai input pada node akan langsung memproses ke hidden layer, node hidden layer pada Gambar 3 menggunakan 10 node. Hubungan hidden layer dan output terjadi proses komputasi terhadap bobot dan bias serta dihitung pula besarnya output dari hidden ke output tersebut berdasarkan fungsi aktivasi sigmoid biner dengan rentang nilai 0 sampai 1 .

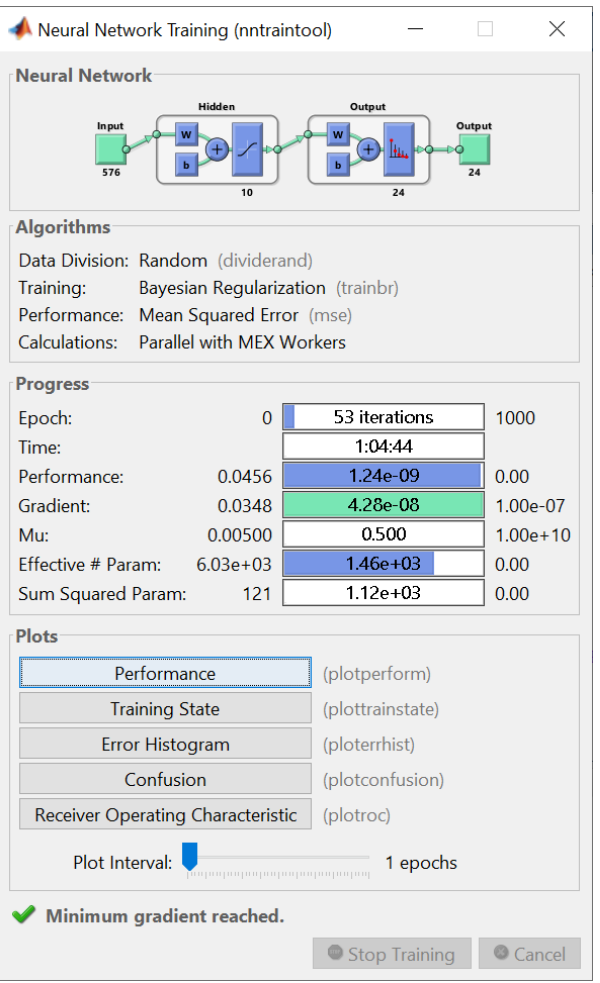

Gambar 8. Pelatihan model JST 


\section{A. Pelatihan JST pada Training Function trainbr}

Training function yang digunakan sebanyak 17 dan jumlah neuron pada hidden layer yang dicoba adalah 5, 10 dan 15 sehingga terdapat 3 arsitektur JST yang berbeda. Tiap arsitektur dicoba sebanyak 3 kali sehingga terdapat 9 percobaan (3 jumlah neuron $\mathrm{x} 3$ percobaan run program).

Hasil percobaan penentuan hidden layer pada function trainbr dilakukan untuk mengenali data latih dan data uji dapat dilihat pada Tabel III dengan jumlah neuron yang digunakan bernilai 5, 10, dan 15 .
Berdasarkan Tabel III dapat disimpulkan bahwa pada neuron 15 merupakan hasil terbaik dalam pengenalan data latih dan data uji yang dicoba sebanyak 3 percobaan run program. Pengenalan data latih yang dicoba sebanyak 3 percobaan run program mendapatkan hasil pengenalan yang baik pada percobaaan ke 1 dan 3 sebesar $91,47 \%$ data yang dikenali, pada neuron 10 hasil terbaik ada dipercobaan ke 2 dengan hasil sebesar $85,91 \%$, sedangkan pada neuron 5 hasil terbaik ada di percobaan ke 1 dengan hasil sebesar $70,4 \%$ data yang dikenali.

TABEL III

Hasil PenguJian MENGgunAKan TRAINING FUNCTION TRAINBR

\begin{tabular}{|c|c|c|c|c|c|c|c|c|}
\hline No. & Neuron & MSE & Epoch & Time & $\begin{array}{l}\text { Data Latih } \\
\text { dikenali }\end{array}$ & $\begin{array}{c}\text { Akurasi } \\
\text { data latih } \\
\text { dikenali }(\%)\end{array}$ & $\begin{array}{l}\text { Data Uji } \\
\text { dikenali }\end{array}$ & $\begin{array}{c}\text { Akurasi } \\
\text { data uji } \\
\text { dikenali }(\%)\end{array}$ \\
\hline 1. & \multirow{3}{*}{5} & $4.49 \mathrm{e}-05$ & 151 & 1 jam 00 menit 21 detik & 1129 & 96 & 353 & 70,04 \\
\hline 2. & & $4.65 \mathrm{e}-05$ & 278 & 1 jam 26 menit 16 detik & 1130 & 96,09 & 348 & 69,05 \\
\hline 3. & & $1.08 \mathrm{e}-04$ & 282 & 1 jam 46 menit 36 detik & 1120 & 95,24 & 349 & 69,25 \\
\hline 4. & \multirow{3}{*}{10} & $1.79 \mathrm{e}-09$ & 34 & 0 jam 45 menit 09 detik & 1162 & 98,81 & 429 & 85,12 \\
\hline 5. & & $1.24 \mathrm{e}-09$ & 53 & 1 jam 04 menit 44 detik & 1159 & 98,55 & 433 & 85,91 \\
\hline 6. & & 4.06e-09 & 38 & 0 jam 46 menit 25 detik & 1157 & 98,38 & 429 & 85,12 \\
\hline 7. & \multirow{3}{*}{15} & $1.94 \mathrm{e}-09$ & 68 & 4 jam 35 menit 34 detik & 1157 & 98,38 & 461 & 91,47 \\
\hline 8. & & $3.10 \mathrm{e}-09$ & 59 & 3 jam 31 menit 49 detik & 1157 & 98,38 & 448 & 88,89 \\
\hline 9. & & $1.94 \mathrm{e}-09$ & 68 & 3 jam 56 menit 11 detik & 1157 & 98,38 & 461 & 91,47 \\
\hline
\end{tabular}

\section{B. Hasil Pengujian JST terhadap 24 huruf menggunakan Training Function trainbr}

Pada tahap ini dilakukan ekstraksi HOG dan klasifikasi JST pada citra ASL. Proses ini dilakukan dengan menggunakan citra uji sebanyak 504 citra untuk dilakukan tahap pengujian. Tahap yang digunakan untuk penentuan hasil pengujian JST yaitu menggunakan 17 training function kemudian dilakukan perhitungan confusion matrix untuk menentukan tingkat akurasi, presisi dan recall. Hasil tingkat akurasi pada pengenalan JST terhadap data uji yang menggunakan confusion matrix dapat dilihat pada Tabel IV, Tabl V dan Tabel VI.

Berdasarkan pada Tabel IV hasil tingkat akurasi keseluruhan menggunakan 5 neuron sebesar 0,97, precision sebesar 0,7 dan recall sebesar 0,7. Akurasi terbesar didapat huruf B sebesar 0,99 sedangkan akurasi terkecil didapat huruf M sebesar 0,96.

TABEL IIV

Hasil Pengujian JST 5 NEURON MENGgunakan TRaINING FunCtion TRAINBR UNTUK 24 HURUF

\begin{tabular}{|c|c|c|c|c|}
\hline No. & Kelas & Accuracy & Precision & Recall \\
\hline 1. & A & 0,98 & 0,84 & 0,76 \\
\hline 2. & B & 0,99 & 0,83 & 0,95 \\
\hline
\end{tabular}

\begin{tabular}{|c|c|c|c|c|}
\hline No. & Kelas & Accuracy & Precision & Recall \\
\hline 3. & $\mathrm{C}$ & 0,98 & 0,81 & 0,81 \\
\hline 4. & $\mathrm{D}$ & 0,96 & 0,59 & 0,48 \\
\hline 5. & $\mathrm{E}$ & 0,98 & 0,65 & 0,95 \\
\hline 6. & $\mathrm{~F}$ & 0,97 & 0,67 & 0,67 \\
\hline 7. & $\mathrm{G}$ & 0,97 & 0,71 & 0,57 \\
\hline 8. & $\mathrm{H}$ & 0,97 & 0,65 & 0,71 \\
\hline 9. & $\mathrm{I}$ & 0,98 & 0,79 & 0,71 \\
\hline 10. & $\mathrm{~K}$ & 0,97 & 0,67 & 0,57 \\
\hline 11. & $\mathrm{~L}$ & 0,98 & 0,72 & 0,86 \\
\hline 12. & M & 0,96 & 0,6 & 0,29 \\
\hline 13. & $\mathrm{~N}$ & 0,97 & 0,71 & 0,57 \\
\hline 14. & $\mathrm{O}$ & 0,98 & 0,71 & 0,81 \\
\hline 15. & $\mathrm{P}$ & 0,98 & 0,8 & 0,76 \\
\hline 16. & Q & 0,97 & 0,63 & 0,9 \\
\hline 17. & $\mathrm{R}$ & 0,97 & 0,67 & 0,57 \\
\hline 18. & S & 0,97 & 0,62 & 0,62 \\
\hline 19. & $\mathrm{~T}$ & 0,97 & 0,6 & 0,71 \\
\hline
\end{tabular}




\begin{tabular}{|c|c|c|c|c|}
\hline No. & Kelas & Accuracy & Precision & Recall \\
\hline 20. & $\mathrm{U}$ & 0,98 & 0,67 & 0,95 \\
\hline 21. & $\overline{\mathrm{V}}$ & 0,98 & 0,81 & 0,62 \\
\hline 22. & $\mathrm{~W}$ & 0,98 & 0,74 & 0,67 \\
\hline 23. & $\bar{X}$ & 0,97 & 0,71 & 0,57 \\
\hline 24. & $\bar{Y}$ & 0,97 & 0,68 & 0,71 \\
\hline \multicolumn{2}{|c|}{ Rata-rata } & 0,97 & 0,70 & 0,70 \\
\hline
\end{tabular}

Berdasarkan pada Tabel $\mathrm{V}$ hasil tingkat akurasi keseluruhan menggunakan 10 neuron sebesar 0,99, precision sebesar 0,87 dan recall sebesar 0,86. Akurasi terbesar didapat huruf $\mathrm{B}, \mathrm{C}, \mathrm{L}, \mathrm{Q}$ dan $\mathrm{Y}$ sebesar 1 dan akurasi terkecil didapat huruf $\mathrm{D}, \mathrm{M}, \mathrm{N}, \mathrm{R}, \mathrm{S}, \mathrm{T}$ dan $\mathrm{W}$ sebesar 0,98 .

TABEL V

Hasil PenguJian JST 10 NEURON MENGGUNAKAN TRAINING FUNCTION TRAINBR UNTUK 24 HURUF

\begin{tabular}{|c|c|c|c|c|}
\hline No. & Kelas & Accuracy & Precision & Recall \\
\hline 1. & $\mathrm{~A}$ & 0,99 & 0,84 & 1 \\
\hline 2. & B & 1 & 0,95 & 0,95 \\
\hline 3. & $\mathrm{C}$ & 1 & 0,95 & 0,95 \\
\hline 4. & $\mathrm{D}$ & 0,98 & 0,7 & 0,76 \\
\hline 5. & E & 0,99 & 0,77 & 0,95 \\
\hline 6. & $\mathrm{~F}$ & 0,99 & 0,88 & 1 \\
\hline 7. & G & 0,99 & 0,89 & 0,81 \\
\hline 8. & $\mathrm{H}$ & 0,99 & 0,85 & 0,81 \\
\hline 9. & I & 0,99 & 0,9 & 0,86 \\
\hline 10. & $\mathrm{~K}$ & 0,99 & 0,95 & 0,86 \\
\hline 11. & $\mathrm{~L}$ & 1 & 1 & 0,9 \\
\hline 12. & $\mathrm{M}$ & 0,98 & 0,71 & 0,71 \\
\hline 13. & $\mathrm{~N}$ & 0,98 & 0,78 & 0,67 \\
\hline 14. & $\mathrm{O}$ & 0,99 & 0,94 & 0,81 \\
\hline 15. & $\mathrm{P}$ & 0,99 & 0,9 & 0,9 \\
\hline 16. & $\mathrm{Q}$ & 1 & 1 & 1 \\
\hline 17. & $\mathrm{R}$ & 0,98 & 0,74 & 0,81 \\
\hline 18. & $S$ & 0,98 & 0,81 & 0,81 \\
\hline 19. & $\mathrm{~T}$ & 0,98 & 0,74 & 0,95 \\
\hline 20. & $\mathrm{U}$ & 0,99 & 0,82 & 0,86 \\
\hline 21. & $\mathrm{~V}$ & 0,99 & 0,86 & 0,86 \\
\hline 22. & $\mathrm{~W}$ & 0,98 & 0,84 & 0,76 \\
\hline 23. & $\mathrm{X}$ & 0,99 & 1 & 0,67 \\
\hline 24. & $\mathrm{Y}$ & 1 & 0,95 & 0,95 \\
\hline \multicolumn{2}{|c|}{ Rata-rata } & 0,99 & 0,87 & 0,86 \\
\hline
\end{tabular}

Berdasarkan pada Tabel VI hasil tingkat akurasi keseluruhan menggunakan 15 neuron sebesar 0,99, precision sebesar 0,92 dan recall sebesar 0,91. Akurasi terbesar didapat huruf B, C, F, L, P, Q dan Y sebesar 1 dan akurasi terkecil didapat huruf $\mathrm{K}$ sebesar 0,98.

TABEL VI

Hasil PenguJian JST 15 NEURON MENGgunakan TRAINING FUNCTION TRAINBR UNTUK 24 HURUF

\begin{tabular}{|c|c|c|c|c|}
\hline No. & Kelas & Accuracy & Precision & Recall \\
\hline 1. & A & 0,99 & 0,88 & 1 \\
\hline 2. & B & 1 & 1 & 1 \\
\hline 3. & C & 1 & 0,95 & 0,95 \\
\hline 4. & D & 0,99 & 0,82 & 0,86 \\
\hline 5. & E & 0,99 & 0,95 & 0,86 \\
\hline 6. & F & 1 & 1 & 1 \\
\hline 7. & G & 0,99 & 0,91 & 0,95 \\
\hline 8. & H & 0,99 & 0,87 & 0,95 \\
\hline 9. & I & 0,99 & 0,95 & 0,86 \\
\hline 10. & K & 0,98 & 0,81 & 0,81 \\
\hline 11. & L & 1 & 0,95 & 1 \\
\hline 12. & M & 0,99 & 0,89 & 0,76 \\
\hline 13. & N & 0,99 & 0,89 & 0,76 \\
\hline 14. & O & 0,99 & 0,95 & 0,9 \\
\hline 15. & P & 1 & 1 & 1 \\
\hline 16. & Q & 1 & 1 & 0,95 \\
\hline 17. & R & 0,99 & 0,89 & 0,81 \\
\hline 18. & S & 0,99 & 0,78 & 1 \\
\hline 19. & T & 0,99 & 0,95 & 0,9 \\
\hline 20. & U & 0,99 & 0,88 & 1 \\
\hline 21. & V & 0,99 & 1 & 0,86 \\
\hline 22. & W & 0,99 & 0,83 & 0,95 \\
\hline 23. & X & 0,99 & 0,9 & 0,86 \\
\hline 24. & Y & 1 & 1 & 0,95 \\
\hline & & 0,99 & 0,92 & 0,91 \\
\hline
\end{tabular}

\section{Hasil Pengujian JST berdasarkan Training Function}

Hasil pengujian pada JST dengan 17 training function dan menggunakan 5 neuron dapat dilihat pada Tabel VII. Berdasarkan Tabel VII, nilai accuracy tertinggi adalah trainbr dengan nilai accuracy sebesar $97,50 \%$, precision sebesar $70,23 \%$, dan recall sebesar $70,04 \%$. Sedangkan accuracy terendah adalah trainb dengan nilai accuracy sebesar 92,54\%, precision terendah pada trains sebesar $4,14 \%$, dan recall terendah pada trainb sebesar $10,53 \%$. 
TABEL VII

Hasil Pengujian Berdasarkan TRAining Function MengGunakan 5 NEURON

\begin{tabular}{|c|c|c|c|c|}
\hline No. & $\begin{array}{c}\text { Training } \\
\text { Function }\end{array}$ & Accuracy & Precision & Recall \\
\hline 1. & Trainbr & 97,5 & 70,23 & 70,04 \\
\hline 2. & Trainlm & 95,68 & 49,44 & 48,21 \\
\hline 3. & Trainbfg & 95,68 & 47,76 & 48,13 \\
\hline 4. & Traincgb & 95,73 & 49,85 & 48,81 \\
\hline 5. & Trancgf & 96,16 & 54,74 & 53,97 \\
\hline 6. & Traincgp & 95,4 & 46,36 & 44,84 \\
\hline 7. & Traingd & 93,16 & 17,95 & 17,88 \\
\hline 8. & Traingda & 94,84 & 30,7 & 38,1 \\
\hline 9. & Traingdm & 92,81 & 7,84 & 13,69 \\
\hline 10. & Traingdx & 96,3 & 53,25 & 55,56 \\
\hline 11. & Trainoss & 96,97 & 66,53 & 63,69 \\
\hline 12. & Trainrp & 94,99 & 37,75 & 39,88 \\
\hline 13. & Trainscg & 96,61 & 58,2 & 59,33 \\
\hline 14. & Trainb & 92,54 & 7,35 & 10,52 \\
\hline 15. & Trainc & 97,45 & 70,1 & 69,44 \\
\hline 16. & Trainr & 97,12 & 66,66 & 65,48 \\
\hline 17. & Trains & 92,66 & 4,14 & 11,9 \\
\hline Rata - Rata & 95,39 & 43,46 & 44,67 \\
\hline
\end{tabular}

Hasil pengujian pada JST dengan 17 training function dan menggunakan 10 neuron dapat dilihat pada Tabel VIII. Berdasarkan Tabel VIII, nilai accuracy tertinggi adalah trainbr dengan nilai accuracy sebesar 98,83\%, precision sebesar 86,57\%, dan recall sebesar 85,91\%. Sedangkan accuracy terendah adalah trains dengan nilai accuracy sebesar $93,4 \%$, precision terendah pada traingd sebesar $17,88 \%$, dan recall terendah pada traingdm sebesar $20,44 \%$.

TABEL VIII

Hasil Pengujian Berdasarkan Training FunCtion MenggunaKan 10 NEURON

\begin{tabular}{|c|c|c|c|c|}
\hline No. & $\begin{array}{c}\text { Training } \\
\text { Function }\end{array}$ & Accuracy & Precision & Recall \\
\hline 1. & Trainbr & 98,83 & 86,57 & 85,91 \\
\hline 2. & Trainlm & 97,85 & 74,88 & 74,21 \\
\hline 3. & Trainbfg & 97,07 & 64,2 & 64,88 \\
\hline 4. & Traincgb & 98,36 & 81,44 & 80,36 \\
\hline 5. & Trancgf & 98,69 & 85,21 & 84,33 \\
\hline 6. & Traincgp & 97,5 & 70,4 & 70,04 \\
\hline 7. & Traingd & 93,39 & 17,88 & 20,63 \\
\hline 8. & Traingda & 95,39 & 46,52 & 44,64 \\
\hline
\end{tabular}

\begin{tabular}{|c|c|c|c|c|}
\hline No. & $\begin{array}{c}\text { Training } \\
\text { Function }\end{array}$ & Accuracy & Precision & Recall \\
\hline 9. & Traingdm & 93,37 & 21,83 & 20,44 \\
\hline 10. & Traingdx & 98,38 & 81,18 & 80,56 \\
\hline 11. & Trainoss & 98,23 & 79,57 & 78,77 \\
\hline 12. & Trainrp & 97,01 & 62,56 & 64,09 \\
\hline 13. & Trainscg & 98,93 & 98,07 & 76,88 \\
\hline 14. & Trainb & 93,68 & 18,54 & 24,21 \\
\hline 15. & Trainc & 98,78 & 86,19 & 85,32 \\
\hline 16. & Trainr & 98,41 & 81,62 & 80,95 \\
\hline 17. & Trains & 93,4 & 22,09 & 20,83 \\
\hline Rata - Rata & 96,9 & 63,46 & 62,18 \\
\hline
\end{tabular}

Hasil pengujian pada JST dengan 17 training function dan menggunakan 15 neuron dapat dilihat pada Tabel IX. Berdasarkan Tabel IX, nilai accuracy tertinggi adalah trainbr dengan nilai accuracy sebesar $99,29 \%$, precision sebesar $91,84 \%$, dan recall sebesar $91,47 \%$. Sedangkan accuracy terendah adalah traingd dengan nilai accuracy sebesar 93,2\%, precision terendah pada traingd sebesar $14,2 \%$, dan recall terendah pada traingd sebesar $18,45 \%$.

TABEL IX

Hasil Pengujian BERdasarkan TRAINING FUNCTION MENGGUNAKAN 15 NEURON

\begin{tabular}{|c|c|c|c|c|}
\hline No. & $\begin{array}{c}\text { Training } \\
\text { Function }\end{array}$ & Accuracy & Precision & Recall \\
\hline 1. & Trainbr & 99,29 & 91,84 & 91,47 \\
\hline 2. & Trainlm & 98,16 & 79,64 & 77,98 \\
\hline 3. & Trainbfg & 97,83 & 74,96 & 74,01 \\
\hline 4. & Traincgb & 98,73 & 85,77 & 84,77 \\
\hline 5. & Trancgf & 98,81 & 86,39 & 85,71 \\
\hline 6. & Traincgp & 98,68 & 85,04 & 84,13 \\
\hline 7. & Traingd & 93,2 & 14,2 & 18,45 \\
\hline 8. & Traingda & 97,3 & 71,51 & 67,66 \\
\hline 9. & Traingdm & 93,7 & 25,45 & 24,4 \\
\hline 10. & Traingdx & 98,86 & 86,76 & 86,31 \\
\hline 11. & Trainoss & 98,93 & 87,57 & 87,1 \\
\hline 12. & Trainrp & 97,59 & 72,75 & 71,03 \\
\hline 13. & Trainscg & 98,93 & 87,48 & 87,1 \\
\hline 14. & Trainb & 93,44 & 19,05 & 21,23 \\
\hline 15. & Trainc & 99,21 & 90,93 & 90,48 \\
\hline 16. & Trainr & 98,91 & 87,76 & 86,9 \\
\hline 17. & Trains & 93,35 & 17,93 & 20,24 \\
\hline \multicolumn{2}{|c|}{ Rata - Rata } & 97,35 & 68,53 & 68,17 \\
\hline
\end{tabular}


Berdasarkan Tabel X, accuracy keseluruhan neuron 5 menghasilkan nilai rata - rata keseluruhan accuracy sebesar $95,38 \%$, neuron 10 menghasilkan nilai rata - rata keseluruhan accuracy sebesar 96,64\% dan neuron 15 menghasilkan nilai rata - rata keseluruhan accuracy sebesar 97,32\%. Jumlah neuron 15 memberikan accuracy yang paling baik

TABEL X

PERBANDINGAN ACCURACY BERDASAKAN TRAINING FUNCTION TERHADAP JUMLAH NEURON

\begin{tabular}{|c|c|c|c|c|}
\hline No. & $\begin{array}{c}\text { Training } \\
\text { function }\end{array}$ & $\begin{array}{c}\mathbf{5} \\
\text { Neuron }\end{array}$ & $\begin{array}{c}\mathbf{1 0} \\
\text { Neuron }\end{array}$ & $\begin{array}{c}\mathbf{1 5} \\
\text { Neuron }\end{array}$ \\
\hline 1. & Trainbr & 97,47 & 98,77 & 99,28 \\
\hline 2. & Trainlm & 95,66 & 97,83 & 98,13 \\
\hline 3. & Trainbfg & 95,65 & 97,09 & 97,8 \\
\hline 4. & Traincgb & 95,85 & 97,36 & 98,71 \\
\hline 5. & Trancgf & 96,17 & 96,54 & 98,79 \\
\hline 6. & Traincgp & 95,29 & 97,54 & 98,68 \\
\hline 7. & Traingd & 93,01 & 93,22 & 93,15 \\
\hline 8. & Traingda & 95,02 & 95,25 & 97,31 \\
\hline 9. & Traingdm & 92,88 & 93,22 & 93,62 \\
\hline 10. & Traingdx & 96,35 & 98,36 & 98,87 \\
\hline 11. & Trainrp & 94,87 & 97,01 & 97,58 \\
\hline 12. & Trainscg & 96,63 & 98,06 & 98,93 \\
\hline 13. & Trainb & 92,52 & 93,59 & 93,36 \\
\hline 14. & Trainc & 97,45 & 98,76 & 99,21 \\
\hline 15. & Trainr & 97,17 & 98,42 & 98,88 \\
\hline 16. & Trains & 92,5 & 93,57 & 93,25 \\
\hline 17. & Trainoss & 96,93 & 98,21 & 98,93 \\
\hline RATA - RATA & 95,38 & 96,64 & 97,32 \\
\hline
\end{tabular}

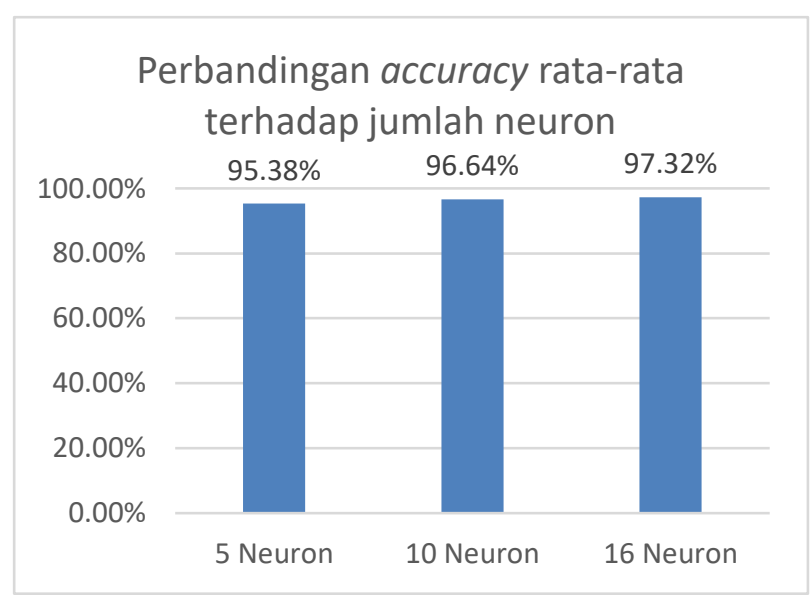

Gambar 9. Perbandingan accuracy 5 neuron, 10 neuron dan 15 neuron
Pada Gambar 9 dari ketiga neuron tersebut dapat dilihat bahwa neuron 15 menghasilkan nilai yang lebih baik. Dari Gambar 9 terlihat bertambah neuron maka accuracy bertambah.

Berdasarkan Tabel XI, precision keseluruhan neuron 5 menghasilkan nilai rata - rata keseluruhan precision sebesar $43,46 \%$, neuron 10 menghasilkan nilai rata - rata keseluruhan precision sebesar $63,46 \%$ dan neuron 15 menghasilkan nilai rata - rata keseluruhan precision sebesar $68,53 \%$.

TABEL XI

PERBANDINGAN PRECISION BERDASARKAN TRAINING FUNCTION TERHADAP JUMLAH NEURON

\begin{tabular}{|c|c|c|c|c|}
\hline No. & $\begin{array}{c}\text { Training } \\
\text { function }\end{array}$ & $\begin{array}{c}\mathbf{5} \\
\text { Neuron }\end{array}$ & $\begin{array}{c}\mathbf{1 0} \\
\text { Neuron }\end{array}$ & $\begin{array}{c}\mathbf{1 5} \\
\text { Neuron }\end{array}$ \\
\hline 1. & Trainbr & 70,23 & 86,57 & 91,84 \\
\hline 2. & Trainlm & 49,44 & 74,88 & 79,64 \\
\hline 3. & Trainbfg & 47,76 & 64,20 & 74,96 \\
\hline 4. & Traincgb & 49,85 & 81,44 & 85,77 \\
\hline 5. & Trancgf & 54,74 & 85,21 & 86,39 \\
\hline 6. & Traincgp & 46,36 & 70,40 & 85,04 \\
\hline 7. & Traingd & 17,95 & 17,88 & 14,20 \\
\hline 8. & Traingda & 30,70 & 46,52 & 71,51 \\
\hline 9. & Traingdm & 7,84 & 21,83 & 25,45 \\
\hline 10. & Traingdx & 53,25 & 81,18 & 86,76 \\
\hline 11. & Trainrp & 66,53 & 79,57 & 87,57 \\
\hline 12. & Trainscg & 37,75 & 62,56 & 72,75 \\
\hline 13. & Trainb & 58,20 & 98,07 & 87,48 \\
\hline 14. & Trainc & 7,35 & 18,54 & 19,05 \\
\hline 15. & Trainr & 70,10 & 86,19 & 90,93 \\
\hline 16. & Trains & 66,66 & 81,62 & 87,76 \\
\hline 17. & Trainoss & 4,14 & 22,09 & 17,93 \\
\hline RATA - RATA & 43,46 & 63,46 & 68,53 \\
\hline
\end{tabular}

Berdasarkan Tabel XII, recall keseluruhan neuron 5 menghasilkan nilai rata - rata keseluruhan recall sebesar $45,67 \%$, neuron 10 menghasilkan nilai rata - rata keseluruhan recall sebesar $62,18 \%$ dan neuron 15 menghasilkan nilai rata - rata keseluruhan recall sebesar $68,17 \%$.

TABEL XII

Perbandingan Recall Berdasarkan Training FunCtion TERHADAP JUMLAH NEURON

\begin{tabular}{|c|c|c|c|c|}
\hline No. & $\begin{array}{c}\text { Training } \\
\text { function }\end{array}$ & $\begin{array}{c}\mathbf{5} \\
\text { Neuron }\end{array}$ & $\begin{array}{c}\mathbf{1 0} \\
\text { Neuron }\end{array}$ & $\begin{array}{c}\mathbf{1 5} \\
\text { Neuron }\end{array}$ \\
\hline 1. & Trainbr & 70,04 & 85,91 & 91,47 \\
\hline 2. & Trainlm & 48,21 & 74,21 & 77,98 \\
\hline 3. & Trainbfg & 48,13 & 64,88 & 74,01 \\
\hline 4. & Traincgb & 48,81 & 80,36 & 84,77 \\
\hline
\end{tabular}




\begin{tabular}{|c|c|c|c|c|}
\hline No. & $\begin{array}{c}\text { Training } \\
\text { function }\end{array}$ & $\begin{array}{c}\mathbf{5} \\
\text { Neuron }\end{array}$ & $\begin{array}{c}\mathbf{1 0} \\
\text { Neuron }\end{array}$ & $\begin{array}{c}\mathbf{1 5} \\
\text { Neuron }\end{array}$ \\
\hline 5. & Trancgf & 53,97 & 84,33 & 85,71 \\
\hline 6. & Traincgp & 44,84 & 70,04 & 84,13 \\
\hline 7. & Traingd & 17,88 & 20,63 & 18,45 \\
\hline 8. & Traingda & 38,10 & 44,64 & 67,66 \\
\hline 9. & Traingdm & 13,69 & 20,44 & 24,40 \\
\hline 10. & Traingdx & 55,56 & 80,56 & 86,31 \\
\hline 11. & Trainrp & 63,69 & 78,77 & 87,10 \\
\hline
\end{tabular}

\begin{tabular}{|c|c|c|c|c|}
\hline No. & $\begin{array}{c}\text { Training } \\
\text { function }\end{array}$ & $\begin{array}{c}\mathbf{5} \\
\text { Neuron }\end{array}$ & $\begin{array}{c}\mathbf{1 0} \\
\text { Neuron }\end{array}$ & $\begin{array}{c}\mathbf{1 5} \\
\text { Neuron }\end{array}$ \\
\hline 12. & Trainscg & 39,88 & 64,09 & 71,03 \\
\hline 13. & Trainb & 59,33 & 76,88 & 87,10 \\
\hline 14. & Trainc & 10,52 & 24,21 & 21,23 \\
\hline 15. & Trainr & 69,44 & 85,32 & 90,48 \\
\hline 16. & Trains & 65,48 & 80,95 & 86,90 \\
\hline 17. & Trainoss & 11,90 & 20,83 & 20,24 \\
\hline \multicolumn{2}{|c|}{ RATA - RATA } & 44,67 & 62,18 & 68,17 \\
\hline
\end{tabular}

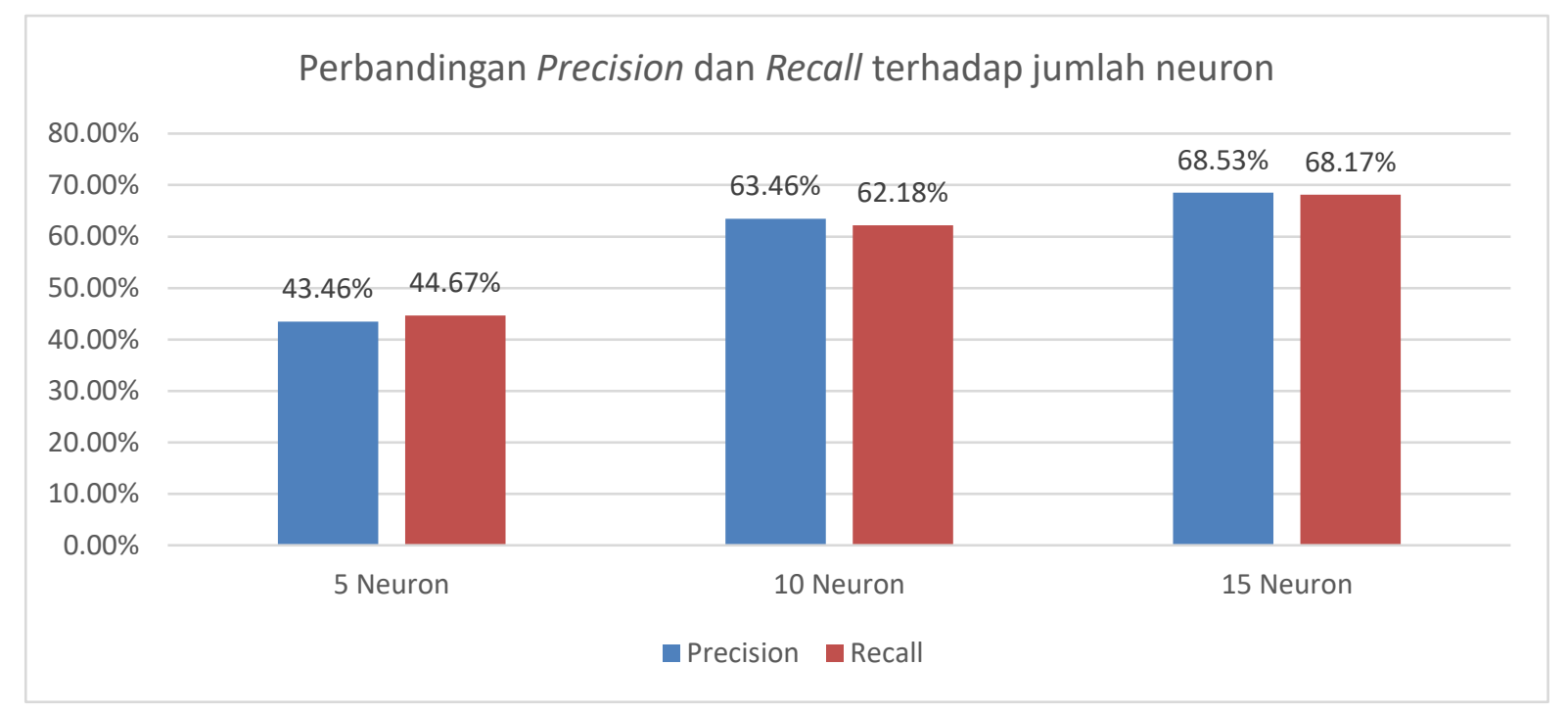

Gambar 10. Perbandingan precision dan recall 5 neuron, 10 neuron dan 15 neuron

Pada Gambar 10 merupakan perbandingan precision dan recall untuk 5, 10 dan 15 neuron. Dari Gambar 10 terlihat bahwa semakin bertambah neuron maka bertambah juga precision dan recall.

Dari 17 training function terlihat trainbr merupakan training function yang memberikan hasil terbaik terlihat dari accuracy, precision dan recall terhadap variasi jumlah neuron.

\section{KESIMPULAN}

Nilai accuracy overall dengan menggunakan training function trainbr memiliki tingkat keberhasilan yang lebih tinggi dibanding dengan penggunaan 16 training function lainnya pada skenario neuron 5,10 dan 15 . Dengan nilai accuracy neuron 5 sebesar 97,47\%, nilai accuracy neuron 10 sebesar $98,77 \%$ dan nilai accuracy neuron 15 sebesar 99,28\%. Nilai precision untuk 5, 10 dan 15 neuron secara terurut yaitu 70,23\%, 86,57\% dan 91,84\%. Nilai recall untuk 5, 10 dan 15 neuron secara terurut yaitu $70,04 \%$, $85,91 \%$, dan $91,47 \%$. Berdasarkan training function dan hasil ekstraksi menggunakan HOG sebagai nilai input pada JST dapat disimpulkan bahwa 17 training function yang menggunakan neuron berjumlah 15 merupakan hasil terbaik dari 3 neuron yang telah diuji yaitu menghasilkan nilai rata
- rata keseluruhan accuracy 5 neuron sebesar 95,38\%, 10 neuron sebesar $96,64 \%$, dan 15 neuron sebesar $97,32 \%$.

\section{DAFTAR PUSTAKA}

[1] I. Mahfudi, M. Sarosa, R. Andrie Asmara, and M. Azrino Gustalika, "Indonesian Sign Language Number Recognition using SIFT Algorithm," in IOP Conference Series: Materials Science and Engineering, 2018, vol. 336, no. 1, p. 012010, doi: 10.1088/1757-899X/336/1/012010.

[2] M. E. Al Rivan, H. Irsyad, K. Kevin, and A. T. Narta, "Pengenalan Alfabet American Sign Language Menggunakan KNearest Neighbors Dengan Ekstraksi Fitur Histogram Of Oriented Gradients," J. Tek. Inform. dan Sist. Inf., vol. 5, no. 3, pp. 328-339, Jan. 2020, doi: 10.28932/jutisi.v5i3.1936.

[3] I. Fareza, R. Busdin, M. E. Al Rivan, and H. Irsyad, "Pengenalan Alfabet Bahasa Isyarat Amerika Menggunakan Edge Oriented Histogram dan Image Matching," J. Tek. Inform. dan Sist. Inf., vol. 4, no. 1, pp. 82-92, Apr. 2018, doi: 10.28932/jutisi.v4i1.747.

[4] N. M, "Alphabet Recognition of American Sign Language: A Hand Gesture Recognition Approach Using Sift Algorithm," Int. J. Artif. Intell. Appl., vol. 4, no. 1, pp. 105-115, Jan. 2013, doi: 10.5121/ijaia.2013.4108.

[5] M. A. Rahayu, R. Magdalena, and R. Rahmania, "Identifikasi Penyakit Kulit Menggunakan Histogram Of Oriented Gradients Dan Jaringan Syaraf Tiruan Identification Of Skin Diseases Using Histogram Of Oriented Gradients And Artificial Neural Network Backpropagation," in e-Proceeding of Engineering, 2019, vol. 6, no. 2, pp. 3951-3958. 
[6] J. V. Vardhan, K. Kaur, and U. Kumar, "Plant Recognition using Hog and Artificial Neural Network," Int. J. Recent Innov. Trends Comput. Commun., vol. 5, no. 5, pp. 746-750, 2017.

[7] S. Devella, "Pengenalan Iris menggunakan Ekstraksi Fitur Histogram of Oriented Gradient," J. Tek. Inform. dan Sist. Inf., vol. 4, no. 1, pp. 124-134, Apr. 2018, doi: 10.28932/jutisi.v4i1.756.

[8] M. E. Al Rivan and T. Juangkara, "Identifikasi Potensi Glaukoma dan Diabetes Retinopati Melalui Citra Fundus Menggunakan Jaringan Syaraf Tiruan," JATISI (Jurnal Tek. Inform. dan Sist. Informasi), vol. 6, no. 1, pp. 43-48, Sep. 2019, doi: 10.35957/jatisi.v6i1.158.

[9] M. E. Al Rivan, N. Rachmat, and M. R. Ayustin, "Klasifikasi Jenis Kacang-Kacangan Berdasarkan Tekstur Menggunakan Jaringan Syaraf Tiruan," J. Komput. Terap., vol. 6, no. 1, pp. 8998, 2020, doi: doi.org/10.35143/jkt.v6i1.3546.

[10] M. Olivya, E. Tungadi, and N. B. Rante, "Klasifikasi Kualitas Biji Kopi Ekspor Menggunakan Jaringan Saraf Tiruan Backpropagation," J. Inf. Sains dan Teknol., vol. 3, no. 2, pp. 299-308, 2018, doi: https://doi.org/10.24252/instek.v3i2.6227.

[11] R. Rahmadewi, E. Purwanti, and V. Efelina, "Identifikasi Jenis Tumbuhan Menggunakan Citra Daun Berbasis Jaringan Saraf
Tiruan (Artificial Neural Networks)," J. Media Elektro, vol. 7, no. 2, pp. 38-43, 2018.

[12] K. M. Lim, K. S. Tan, A. W. C. Tan, S. C. Tan, C. P. Lee, and S F. A. Razak, "Finger spelling recognition using neural network," in 2015 IEEE Student Conference on Research and Development (SCOReD), 2015, pp. 78-81, doi: 10.1109/SCORED.2015.7449437.

[13] H. Hosoe, S. Sako, and B. Kwolek, "Recognition of JSL finger spelling using convolutional neural networks," in 2017 Fifteenth IAPR International Conference on Machine Vision Applications (MVA), 2017, pp. 85-88, doi: 10.23919/MVA.2017.7986796.

[14] D. Amputri, S. Nadra, G. Gasim, and M. E. Al Rivan, "Perbandingan jarak potret dan resolusi kamera pada tingkat akurasi pengenalan angka kwh metermenggunakan svm," $J$. Inform. Glob., vol. 8, no. 1, pp. 7-12, 2017, doi: http://dx.doi.org/10.36982/jig.v8i1.218.

[15] S. Sreehari, "Sign Language and Static-Gesture Recognition using scikit-learn," 2017. [Online]. Available: https://www.freecodecamp.org/news/weekend-projects-signlanguage-and-static-gesture-recognition-using-scikit-learn$60813 \mathrm{~d} 600 \mathrm{e} 79 /$. 